\title{
EFEKTIVITAS PENGGUNAAN MEDIA PEMBELAJARAN FLIP BOOK TERHADAP PENINGKATAN HASIL BELAJAR SISWA PADA MATA PELAJARAN PAI DAN BUDI PEKERTI DI SMA NEGERI 4 BANDUNG
}

\author{
Yuli Wahyuliani, * \\ Udin Supriadi, Saepul Anwar \\ Program Studi Ilmu Pendidikan Agama Islam, \\ Fakultas Pendidikan Ilmu Pengetahuan Sosial, Universitas Pendidikan Indonesia \\ *Email: wahyuliani.811@gmail.com
}

\begin{abstract}
ABSTRAK
Sebagaimana kehidupan, dunia pendidikan tidak luput dari suatu permasalahan. Termasuk permasalahan yang terjadi dalam mata pelajaran Pendidikan Agama Islam (PAI). Terkadang dalam beberapa kesempatan, siswa mengidentikkan pembelajaran PAI dengan mengantuk dan monoton, sehingga beberapa siswa kurang menguasai materi pembelajaran PAI. Kurangnya penggunaan media pembelajaran dalam materi-materi PAI, menjadi salah satu permasalahan yang diindikasikan membuat siswa kurang menangkap materi pembelajaran. Salah satu media pembelajaran yang dapat digunakan sebagai inovasi dalam proses pembelajaran PAI adalah flip book. Flip book merupakan lembaran-lembaran kertas menyerupai album atau kalender berukuran 11 x $13 \mathrm{~cm}$. Media ini bisa digunakan perindividu atau kelompok. Adapun tujuan dari penelitian ini adalah untuk mengetahui efektivitas penggunaan media pembelajaran flip book terhadap peningkatan hasil belajar peserta didik pada mata pelajaran PAI dan budi pekerti di SMA Negeri 4 Bandung. Metode yang digunakan dalam penelitian ini adalah metode penelitian eksperimen dengan quasi experimental design. Adapun jenis desain eksperimen semu dari penelitian ini yaitu desain nonequivalent control group design, dimana kelompok eksperimen maupun kontrol tidak dipilih secara random. Untuk instrumen yang digunakan berupa tes objektif ranah kognitif dengan bentuk soal pilihan ganda. Sedangkan, untuk analisis data meliputi analisis uji normalitas, uji homogenitas, perhitungan gain ternormalisasi, uji t-test yang terdiri dari uji paired sample test dan uji independent sample test. Hasil pengolahan data dengan uji independent sample test, data post-test kelas eksperimen dan kontrol, menunjukkan nilai sig. (2-tailed) sebesar 0,617 >0,05, maka sesuai dasar pengambilan keputusan, jika nilai sig.(2tailed) $>0,05$ maka $\mathrm{H}_{\mathrm{o}}$ diterima dan $\mathrm{H}_{\mathrm{a}}$ ditolak atau dengan kata lain tidak terdapat perbedaan yang signifikan. Dengan demikian, media pembelajaran flip book yang digunakan oleh kelas eksperimen, tidak lebih efektif dari kelas kontrol dalam peningkatan hasil belajar siswa pada mata pelajaran PAI dan Budi Pekerti di SMA Negeri 4 Bandung.
\end{abstract}

Kata kunci: Efektivitas, Media Flip Book, PAI, Hasil Belajar Siswa

TARBAWY, Vol. 3, Nomor 1, (2016) | 22 


\section{PENDAHULUAN}

Sebagaimana kehidupan, dunia pendidikan tidak luput dari suatu permasalahan. Termasuk permasalahan yang terjadi dalam mata pelajaran Pendidikan Agama Islam (PAI). Terkadang dalam beberapa kesempatan, siswa mengidentikkan pembelajaran PAI dengan mengantuk dan monoton, sehingga beberapa siswa kurang menguasai materi pembelajaran PAI. Kurangnya penggunaan media pembelajaran dalam materi-materi PAI, menjadi salah satu permasalahan yang diindikasikan membuat siswa kurang menangkap materi pembelajaran.

Dari permasalahan tersebut, solusi yang efektif bagi keberhasilan pembelajaran PAI harus secepatnya dilaksanakan. Karena, pembelajaran PAI bukan hanya sekedar transfer imu semata, tetapi tranfer nilai-nilai agama yang menjadi dasar dari kehidupan manusia. Maka dari itu, salah satu solusi dari permasalahan tersebut adalah penggunaan media pembelajaran.

Media pembelajaran merupakan salah satu bagian dari sistem pembelajaran yang digunakan sebagai sarana penyampaian pesan informasi edukatif antara pendidik dan peserta didik, sehingga mampu menciptakan suasana pembelajaran yang efektif dan efisien.

Media pembelajaran memiliki fungsi dan peran sebagai pembawa informasi dari sumber informasi itu sendiri (guru) menuju penerima informasi (siswa). Sedangkan metode penyampaian media yang digunakan oleh guru merupakan prosedur yang dapat membantu siswa dalam menerima dan mengolah informasi tertentu menjadi pemahaman dasar dari kumpulankumpulan informasi mentah menjadi wacana ilmu pengetahuan.

Adapun mengenai manfaat dari media pembelajaran, Midun dalam Asyhar (2012, hlm. 41) menyebutkan ada beberapa manfaat media pembelajaran, antara lain:
1. Siswa akan memperoleh pengalaman beragam selama proses pembelajaran.

2. Dapat menambah kemenarikan tampilan materi sehingga meningkat motivasi dan minat serta mengambil perhatian siswa untuk fokus mengikuti materi yang disajikan, sehingga diharapkan efektivitas belajar akan meningkat pula.

3. Media pembelajaran dapat merangsang siswa untuk berfikir kritis, menggunakan kemampuan imajinasinya, bersikap dan berkembang lebih lanjut, sehingga melahirkan kreativitas dan karyakarya inovatif.

Dari beberapa manfaat media pembelajaran di atas, media pembelajaran menjadi salah satu komponen yang berpengaruh dalam keberhasilan proses pembelajaran. Adapun media pembelajaran yang dapat digunakan dalam pembelajaran PAI dan Budi Pekerti salah satunya adalah media flip book. Flip book merupakan lembaran-lembaran kertas menyerupai album atau kalender berukuran 11 x $13 \mathrm{~cm}$. Media ini bisa digunakan perindividu atau kelompok, 
tetapi hanya sampai 4-5 orang. Dengan bentuknya yang kecil, media ini dapat dibawa kemana-mana dan bisa dimasukan ke kantong baju sehingga siswa bisa belajar dimanapun dan kapan pun dengan media flip book ini (Anwar : 2014).

Secara umum, proses produksi media flip book terdiri dari tiga tahap, yaitu pra produksi, produksi dan pasca produksi. Adapun rinciannya adalah sebagai berikut :

a. Tahap pra produksi meliputi kegiatan perencanaan dalam tahap persiapan pembuatan flip book. Adapun tahapannya adalah sebagai berikut :

1) Menelaah tujuan pemebelajaran. Hal ini menjadi acuan dari penyusunan isi dari flip book tersebut.

2) Menyusun jabaran materi untuk dijadikan sebagai isi dari flip book.

3) Materi yang telah dijabarkan, disusun menjadi rangkuman yang mewakili dari indikator pembelajaran dari materi tersebut.

4) Mempersiapkan alat dan bahan yang akan digunakan untuk pembuatan fisik flip book, seperti kertas (boleh menggunakan berbagai jenis kertas) serta bahan lainnya untuk hiasan flip book, gunting dan lain-lain.

b. Tahap produksi meliputi kegiatan langkah-langkah pembuatan flip book. Adapun rinciannya adalah sebagai berikut :

1) Pembuatan flip book bisa manual atau dibuat secara hand made, atau bisa dengan bantuan aplikasi komputer, misalnya aplikasi Ms. Powerpoint, Photoshop dan lainlain.
2) Mengatur ukuran kertas yang akan dijadikan flip book. Adapun ukuran yang dipakai biasanya berkisar $10 \mathrm{~cm}$ x $13 \mathrm{~cm}$, seperti ukuran kalender kecil.

3) Menentukan desain flip book sesuai keinginan.

4) Memasukkan materi-materi yang telah dirangkum pada tahap pra produksi.

5) Membubuhkan hiasan-hiasan maupun gambar sesuai kebutuhan.

c. Tahap pasca produksi adalah tahap akhir dari pembuatan media. Tahap ini merupakan sentuhan akhir sebelum dimanfaatkan. Adapun tahap pasca prosuksi antara lain meliputi:

1) Editing. Hal ini dilakukan untuk mengecek kembali isi maupun desain flip book.

2) Revisi kekurangan yang ada dalam isi maupun desain flip book sehingga sesuai dengan perencanaan yang telah dibuat.

3) Flip book sudah bisa untuk digunakan sebagai media pembelajaran. Flip book ini bisa digunakan secara individu maupun kelompok.

Seperti halnya media pembelajaran lainnya, flip book mempunyai keistimewaan tersendiri. Adapun keistimewaan dari flip book antara lain, dengan menggunakan media pembelajaran flip book, siswa diajak untuk mengembangkan kreatifitasnya. Hal ini karena dalam pembuatan flip book baik itu flip book yang sudah ada maupun buatan tangan siswa, biasanya dibubuhkan gambar-gambar atau hiasan lainnya sesuai keinginan siswa, sehingga rangkuman yang terdapat dalam flip book menarik untuk dibaca. 
Dengan menggunakan media flip book, diharapkan mampu membantu tercapainya tujuan pembelajaran. Salah satu indikator keberhasilan belajar siswa antara lain adalah terjadinya perubahan dalam ranah kognitif afektif maupun psikomotor siswa. Keterpaduan tiga ranah tersebut diaplikasikan dalam proses pembelajaran.

Wahidmurni, dkk. (2010, hlm. 18) menjelaskan bahwa seseorang dapat dikatakan telah berhasil dalam belajar jika ia mampu menunjukkan adanya perubahan dalam dirinya. Perubahanperubahan tersebut di antaranya dari segi kemampuan berpikirnya, keterampilannya, atau sikapnya terhadap suatu objek.

Penilaian hasil belajar mengisyaratkan hasil belajar sebagai program atau objek yang menjadi sasaran penilaian. Hasil belajar sebagai objek penilaian pada hakikatnya menilai penguasaan siswa terhadap tujuan-tujuan intruksional. Hal ini menggambarkan kemampuan siswa setelah menerima pembelajaran atau menyelesaikan pengalaman belajarnya (Sudjana, 2009, hlm. 34).

Berdasarkan pernyataan di atas, diketahui bahwa hasil belajar merupakan suatu perubahan yang terjadi kepada peserta didik meliputi perubahan kognitif, afektif dan psikomotor yang dimiliki oleh peserta didik. Karena pada hakikatnya hasil dari seseorang belajar adalah perubahan, baik perubahan itu menuju arah peningkatan, pengembangan ataupun penurunan.

\section{METODE}

Penelitan ini dilaksanakan di Sekolah Menengah Atas (SMA) Negeri 4 Bandung yang bertempat di Gardujati No. 20 Kota Bandung pada semester genap tahun ajar 2015/2016 dari bulan Februari sampai Maret 2016. Pada penelitian ini yang menjadi subjek penelian adalah seluruh siswa kelas XI MIA SMA Negeri 4 Bandung. Sedangkan yang dijadikan sebagai sampel adalah siswa kelas XI MIA 4 berjumlah 36 siswa dan XI MIA 5 berjumlah 33 siswa.

Pendekatan yang digunakan dalam penelitian ini adalah pendekatan kuantitatif. Sementara, metode yang digunakan adalah metode penelitian eksperimen. Penelitian ekspererimen merupakan upaya perbandingan mengenai akibat suatu tritment dengan suatu tritment lainnya yang berbeda. Dalam penelitian eksperimen, biasanya dibuatkan dua kelompok yaitu kelompok eksperimen dan kelompok kontrol (Taniredja \& Mustafidah, 2012, hlm. 54).

Adapun desain penelitian yang digunakan dalam penelitian ini adalah desain eksperimental semu (quasi experimental design). Dengan jenis desain nonequivalent control group design. Dimana pada desain ini kelompok eksperimen maupun kontrol tidak dipilih secara random. Untuk prosedur tahapan penelitian, dapat divisualisasikan pada gambar 1 sebagai berikut : 


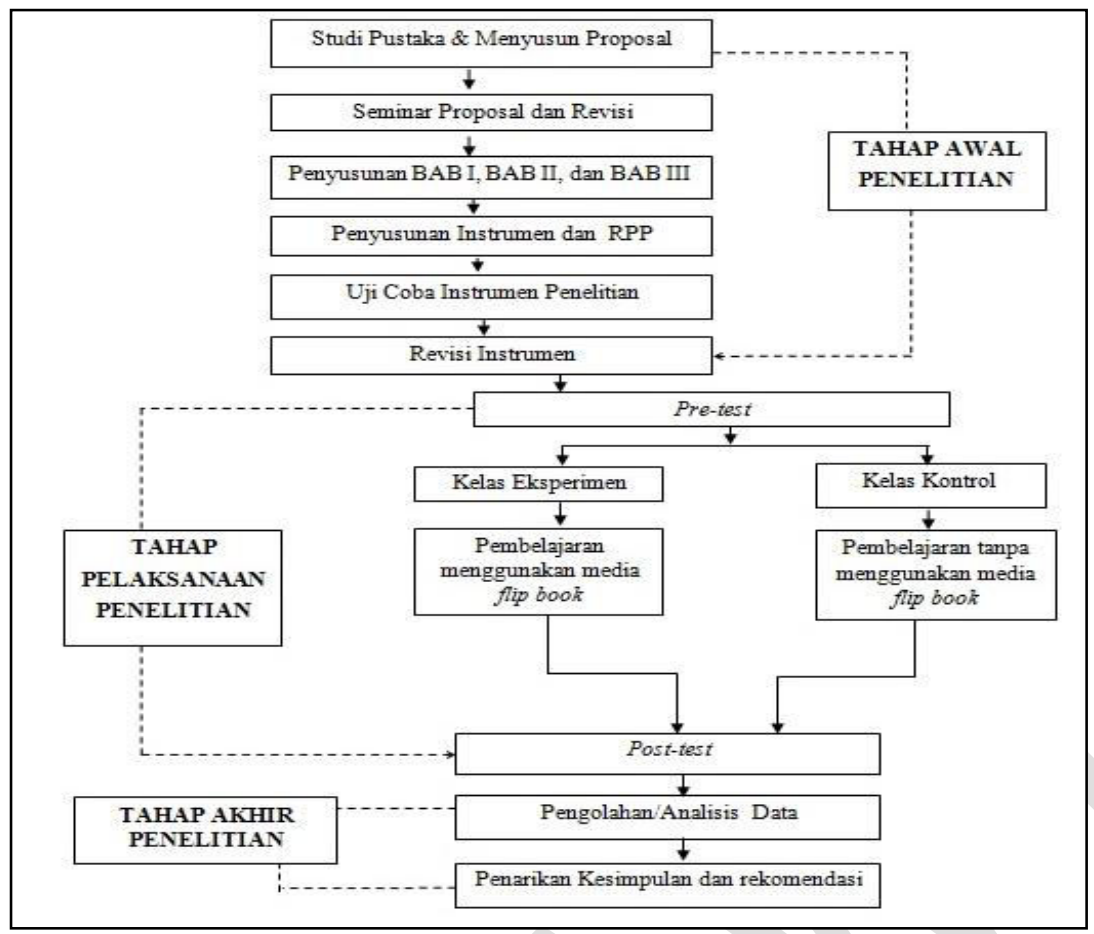

Gambar 1

Tahapan-tahapan Penelitian

Instrumen yang digunakan dalam penelitian ini berupa tes objektif menyangkut ranah kognitif dengan bentuk soal pilihan ganda. Dalam menjawab pertanyaan responden diberikan pilihan a, b, c, d, dan e dalam setiap pertanyaan. Soal dibuat sendiri oleh peneliti berdasarkan kurikulum SMA. Adapun soal yang dijadikan sebagai pre-test dan post-test berjumlah 60 soal. Untuk mengetahui perbandingan hasil tes yang bisa diandalkan, maka soal yang digunakan untuk pre-test dan post-test adalah soal yang sama.

Pengujian data penelitian meliputi

\section{Statistik Deskriptif}

Data yang dianalisis secara deskriptif adalah data hasil belajar siswa, berikut peningkatannya. Adapun analisis deskriptif meliputi pengolahan skor menjadi nilai.
Untuk menginterpretasikan nilai tersebut, digunakan interpretasi sesuai Permendikbud No. 104 Tahun 2014 Interpretasi dapat dilihat pada tabel berikut. 
Tabel 1

Predikat dan Interpretasi Nilai

\begin{tabular}{|c|c|c|c|}
\hline $\begin{array}{c}\text { INTERVAL } \\
\text { NILAI }\end{array}$ & $\begin{array}{c}\text { HASIL } \\
\text { KONVERSI }\end{array}$ & PREDIKAT & INTERPRETASI \\
\hline $96-100$ & 4,00 & A & \multirow{2}{*}{ Sangat baik } \\
\hline $91-95$ & 3,66 & A- & \\
\hline $85-90$ & 3,33 & $\mathrm{~B}+$ & \multirow{3}{*}{ Baik } \\
\hline $80-84$ & 3,00 & $\mathrm{~B}$ & \\
\hline $75-79$ & 2,66 & B- & \\
\hline $70-74$ & 2,33 & $\mathrm{C}+$ & \multirow{3}{*}{ Cukup } \\
\hline $65-69$ & 2,00 & $\mathrm{C}$ & \\
\hline $60-64$ & 1,66 & $\mathrm{C}-$ & \\
\hline $55-59$ & 1,33 & $\mathrm{D}+$ & \multirow{2}{*}{ Kurang } \\
\hline$\leq 54$ & 1,00 & $\mathrm{D}$ & \\
\hline
\end{tabular}

1. Gain Ternormalisasi

Analisis data gain ternormalisasi digunakan untuk mengetahui ada atau tidaknya peningkatan nilai dari kelas eksperimen dan kontrol. Peningkatan ini dilihat dari nilai pre-test dan post-test dari masing-masing kelas. Adapun rumus untuk mencari gain ternormalisasi menurut Hake (1998, hlm. 65) adalah :

$$
G T=\frac{\text { Npre }- \text { Npost }}{\text { Nmaks }- \text { Npre }}
$$

\section{Keterangan :}

GT = Gain ternormalisasi

Npre = Nilai pre-test

Npost $=$ Nilai post-test

Nmaks = Nilai maksimum
Adapun interpretasi dari gain ternormalisasi adalah sebagai berikut:

Tabel 2

Interpretasi Gain Ternormalisasi

\begin{tabular}{|c|c|}
\hline GAIN & INTERPRETASI \\
\hline $\mathrm{g} \geq$ & Tinggi \\
0,7 & \\
\hline $0,7>$ & \\
$\mathrm{g} \geq$ & Sedang \\
0,3 & \\
\hline $\mathrm{g}<$ & Rendah \\
0,3 & \\
\hline
\end{tabular}

Sumber : (Hake, 1998, hlm. 65)

\section{Uji Hipotesis}

Sebelum data yang diperoleh digunakan untuk menguji hipotesis dalam penelitian, data tersebut harus berdistribusi normal dan homogen. Dalam hal ini, data yang didapat dari data pretest dan data post-test, masing-masing dilakukan uji normalitas dan uji homogenitasnya. Adapun rinciannya adalah :

a. Uji Normalitas

Tujuan dari uji normalitas adalah untuk mengetahui apakah data yang 
dipakai berdistrubusi normal atau tidak normal. Adapun beberapa teknik yang dapat digunakan dalam pengujian normalitas data antara lain, melalui rumus Kolmogorov-Smirnov, ShapiroWilk, Chi Square atau Chi Kuadrat dan sebagainya.

Dalam penelitian ini, peneliti menggunakan uji Chi Square untuk menguji normalitas data. Adapun langkah-langkah pengujian normalitas data menggunakan uji Chi Square meliputi :

1) Merumuskan Hipotesis

$$
\mathrm{H}_{\mathrm{o}}=\text { Data berdistribusi }
$$
normal

$\mathrm{H}_{\mathrm{a}}=$ Data berdistribusi tidak normal.

2) Kriteria Pengujian Hipotesis

Dalam pengujian hipotesis uji normalitas data dengan Chi Square, ada beberapa kriteria yang dapat digunakan, yaitu ;

a) Dengan membandingkan antara nilai chi kuadrat ${ }_{\text {hitung }}$ dengan chi kuadrat tabel $_{\text {. }}$. Adapun ketentuannya adalah jika nilai chi kuadrat ${ }_{\text {hitung }}<$ chi kuadrat $_{\text {tabel }}$ maka $\mathrm{H}_{\mathrm{o}}$ diterima dan $\mathrm{H}_{\mathrm{a}}$ ditolak, berarti data berdistribusi normal, sedangkan jika nilai chi kuadrat $_{\text {hitung }}>$ chi kuadrat tabel maka $\mathrm{H}_{\mathrm{o}}$ ditolak dan $\mathrm{H}_{\mathrm{a}}$ diterima, berarti data berdistribusi tidak normal.

b) Dengan melihat signifikansi asymp. Signifikansi asymp ini dapat dilihat dari output SPSS pengolahan data dengan $C h i$ Square. Adapun ketentuannya adalah jika nilai signifikansi asymp $>0,05$ maka data berdistribusi normal, sedangkan jika nilai signifikansi asymp $<0,05$ maka data berdistribusi tidak normal.

3) Cara menghitung Chi Square

Untuk menghitung nilai Chi Square secara manual, dapat menggunakan rumus berikut:

$$
\chi^{2}=\sum_{i=1}^{k} \frac{(f o-f e)^{2}}{f e}
$$

Keterangan :

$\mathrm{x}^{2}=$ Chi Kuadrat

fo $=$ Frekuensi hasil observasi dari sampel penelitian

$\mathrm{fe}=$ Frekuensi yang diharapkan pada populasi penelitian, dengan membagikan jumlah subjek dalam sampel dengan kategori subjek.

b. Uji Homogenitas

Uji homogenitas dimaksudkan untuk memperliharkan bahwa dua atau lebih kelompok data sampel, berada dari populasi yang memiliki variansi yang sama. Adapun teknik dalam pengujian homogenitas dapat menggunakan beberapa teknik, antara lain dengan uji Bartlet, uji $\mathrm{F}$ dan sebagainya.

Dalam penelitian ini, peneliti menggunakan uji $\mathrm{F}$ untuk mengolah data dalam uji homogenitas. Adapun langkah-langkah pengujian normalitas data menggunakan uji F meliputi :

1) Menentukan hipotesis

$\mathrm{H}_{\mathrm{o}}=$ Varian kedua kelompok data homogeny

$\mathrm{H}_{\mathrm{a}}=$ Varian kedua kelompok data tidak homogeny

2) Kriteria Pengujian Hipotesis

Kriteria dalam pengujian homogenitas dengan uji $\mathrm{F}$ yaitu, jika $F_{\text {hitung }}<F_{\text {tabel }}$ maka $\mathrm{H}_{\mathrm{o}}$ diterima dan 
$\mathrm{H}_{\mathrm{a}}$ ditolak , berarti varian kedua kelompok data tersebut adalah homogen. Jika sebaliknya $F_{\text {hitung }}>$

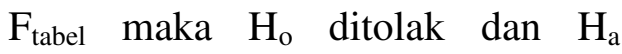
diterima, dapat dinyatakan bahwa varian kedua kelompok data tersebut adalah tidak homogen.

3) Cara menghitung Uji F

Uji homogenitas atau uji varian dapat dilakukan dengan menggunakan rumus :

$$
F_{\text {Hitung }}=\frac{\text { Varian besar }}{\text { Varian kecil }}
$$

Dan untuk menentukan $\mathrm{F}_{\text {tabel }}$ menggunakan rumus:

$$
d f_{1}=k-1
$$$$
d f_{2}=n-k
$$

\section{Keterangan :}

$\mathrm{k}=$ jumlah variable penelitian $\mathrm{n}=$ jumlah sampel

c. Pengujian Hipotesis: Uji Beda

Pengujian hipotesis dalam penelitian ini menggunakan uji beda. Dimana, ketika data berdistribusi normal, maka menggunakan statistik parametrik, dan ketika data berdistribusi tidak normal maka menggunakan statistik non parametrik. Sekaitan dengan penelitian ini, ketika data berdistribusi normal, maka rumus statistik yang akan digunakan adalah uji $t$, karena membandingkan rata-rata dari dua kelompok yang berbeda dan jumlah sampel kurang dari 100 .

$$
\text { Uji statistik parametrik }
$$
dikelompokkan dalam dua pengujian, yaitu :

1) Uji independent samples test Yaitu membandingkan rata-rata nilai pre-test atau post-test pada kelompok yang berbeda. Adapun langkah-langkah pengujian normalitas data menggunakan uji independent samples test meliputi :

a) Menentukan hipotesis

$\mathrm{H}_{\mathrm{o}}=$ Rata-rata hasil belajar pre-test siswa kelas eksperimen dan kontrol adalah sama

$\mathrm{H}_{\mathrm{a}}=$ Rata-rata hasil belajar pre-test siswa kelas eksperimen dan kontrol adalah berbeda. atau

$\mathrm{H}_{\mathrm{o}}=$ Rata-rata hasil belajar post-test siswa kelas eksperimen dan kontrol adalah sama

$\mathrm{H}_{\mathrm{a}}=$ Rata-rata hasil belajar post-test siswa kelas eksperimen dan kontrol adalah berbeda.

\section{b) Kriteria Pengujian Hipotesis}

Jika nilai sig.(2-tailed) $>0,05$, maka Ho di terima dan Ha di tolak. Sedangkan jika nilai sig.(2-tailed) $<0,05$, maka Ho ditolak dan Ha diterima.

c) Cara menghitung uji independent samples test

$$
t=\frac{x_{1}-x_{2}}{\sqrt{\frac{\left(n_{1}-1\right) s_{1}^{2}-\left(n_{2}-1\right) s_{2}^{2}}{n_{1}+n_{2}-2}\left(\frac{1}{n_{1}}\right)+\left(\frac{1}{n_{2}}\right)}}
$$

Sumber : (Sugiyono, 2010, hlm. 138)

Keterangan :

$\mathrm{x}_{1}=$ Rata-rata kelompok 1

$\mathrm{x}_{2}=$ Rata-rata kelompok 2

$\mathrm{s}_{1}=$ Standar deviasi kelompok 1

$\mathrm{s}_{2}=$ Standar deviasi kelompok 2

$\mathrm{n}_{1}=$ Banyaknya sampel kelompok 1

$\mathrm{n}_{2}=$ Banyaknya sampel kelompok 2

2) Uji paired samples test 
Yaitu membandingkan rata-rata nilai pre-test dan post-test pada kelompok yang sama. Adapun langkah-langkah pengujian normalitas data menggunakan uji paired samples test meliputi :

a) Menentukan hipotesis

\begin{tabular}{|c|c|}
\hline $\mathrm{H}_{\mathrm{o}}=$ & $\begin{array}{l}\text { Rata-rata nilai pre-test dan } \\
\text { post-test siswa kelas } \\
\text { eksperimen adalah sama }\end{array}$ \\
\hline $\mathrm{H}_{\mathrm{a}}=$ & $\begin{array}{l}\text { Rata-rata nilai pre-test dan } \\
\text { post-test siswa kelas } \\
\text { eksperimen adalah berbeda. } \\
\text { atau }\end{array}$ \\
\hline $\mathrm{H}_{\mathrm{o}}=$ & $\begin{array}{l}\text { Rata-rata nilai pre-test dan } \\
\text { post-test siswa kelas kontrol } \\
\text { adalah sama }\end{array}$ \\
\hline $\mathrm{H}_{\mathrm{a}}=$ & $\begin{array}{l}\text { Rata-rata nilai pre-test dan } \\
\text { post-test siswa kelas kontrol } \\
\text { adalah berbeda }\end{array}$ \\
\hline
\end{tabular}

b) Kriteria Pengujian Hipotesis Jika nilai sig.(2-tailed) $>0,05$, maka $\mathrm{H}_{\mathrm{o}}$ di terima dan $\mathrm{H}_{\mathrm{a}}$ di tolak. Sedangkan jika nilai sig.(2-tailed) $<0,05$, maka $\mathrm{H}_{\mathrm{o}}$ ditolak dan $\mathrm{H}_{\mathrm{a}}$ diterima.

c) Cara menghitung uji paired samples test

$$
t=\frac{x_{1}-x_{2}}{\sqrt{\frac{s_{1}^{2}}{n_{1}}+\frac{s_{2}^{2}}{n_{2}}-2 r\left(\frac{s_{1}}{\sqrt{n_{1}}}\right)\left(\frac{s_{2}}{\sqrt{n_{2}}}\right)}}
$$

Sumber : (Sugiyono, 2010, hlm. 122)

Sementara, uji statistik non parametrik dikelompokkan dalam dua pengujian sebagai berikut :

1) Uji Mann Whitney
Sama halnya dengan uji independent samples test, uji mann whitney juga digunakan untuk membandingkan rata-rata nilai pre-test atau post-test pada kelompok yang berbeda.

Ketentuan pengujian hipotesis yaitu $\mathrm{H}_{\mathrm{o}}$ diterima dan $\mathrm{H}_{\mathrm{a}}$ ditolak jika $\mathrm{U}_{\text {hitung }}<\mathrm{U}_{\text {tabel }}$, sedangkan jika $\mathrm{U}_{\text {hitung }}<$ $\mathrm{U}_{\text {tabel }}$ maka $\mathrm{H}_{\mathrm{o}}$ ditolak dan $\mathrm{H}_{\mathrm{a}}$ diterima. Adapun rumus Uji $U$ adalah sebagai berikut :

$$
\begin{aligned}
& U_{1=} n_{1} n_{2}+\frac{n_{1\left(n_{1}+1\right)}}{2}-R_{1} \\
& U_{2}=n_{1} n_{2}+\frac{n_{2\left(n_{2}+1\right)}}{2}-R_{2}
\end{aligned}
$$

Sumber : (Sugiyono, 2010, hlm. 153)

Keterangan:

$n_{1}=$ ukuran sampel yang pertama

$n_{2}=$ ukuran sampel yang kedua

$\mathrm{U}_{1}=$ jumlah peringkat 1

$\mathrm{U}_{2}=$ jumlah peringkat 2

$R_{1}=$ peringkat (rank) sampel yang pertama

$R_{2}=$ peringkat (rank) sampel yang kedua

\section{2) Uji Wilcoxon}

Uji wilcoxon ini digunakan untuk membandingkan rata-rata nilai pre-test dan post-test pada kelompok yang sama. Sama halnya seperti uji paired samples test.

Ketentuan pengujian hipotesis yaitu, jika To $\geq \mathrm{T}$ maka Ho diterima dan Ha ditolak. Jika To $<$ T maka Ho ditolak dan $\mathrm{Ha}$ diterima. Adapun rumus Uji z adalah sebagai berikut :

$$
Z=\frac{T-E(T)}{\sigma_{T}}
$$

Sumber : (Sugiyono, 2010, hlm. 136)

Untuk keseluruhan pengolahan analisis data, dalam penelitian ini menggunakan bantuan software SPSS 21 untuk menghitung data uji normalitas dan uji t-test. Sedangkan untuk uji 
homogenitas, menggunakan Microsoft Office Excel 2007.

\section{HASIL DAN PEMBAHASAN}

Kondisi awal kelas eksperimen dengan data nilai pre-test, ditemukan bahwa rata-rata nilai pre-test kelas eksperimen sebesar 56,13 dengan interpretasi kurang. Sementara untuk kelas kontrol, ditemukan rata-rata nilai pre-test sebesar 57,84 dengan interpretasi kurang. Setelah dilakukan pengujian perbedaan rata-rata nilai pre-test kelas eksperimen dan kontrol dengan uji independent sample test.

Adapun pengolahan data untuk uji independent sample t-test, dibantu dengan aplikasi SPSS 21 sebagai berikut:

Tabel 3

Output Independent Samples t-test Pre-test

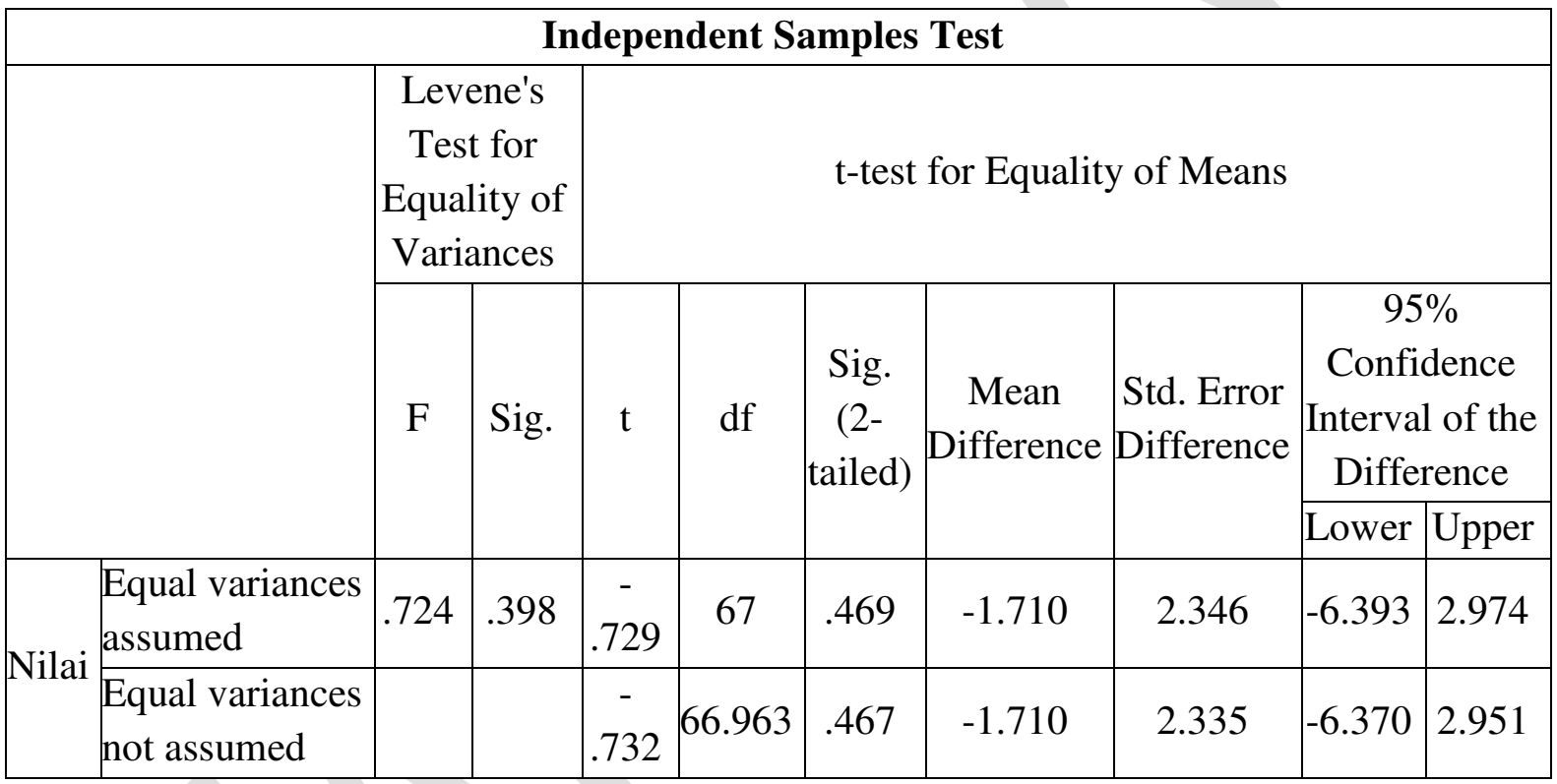

Berdasarkan output di atas, karena diketahui data homogen, maka nilai yang diambil adalah nilai equal variances assumed. Diperoleh bahwa nilai sig. (2tailed) sebesar 0,469>0,05, maka sesuai ketentuan, dapat diketahui bahwa tidak terdapat perbedaan signifikan antara nilai rata-rata pre-test kelas eksperimen dan nilai rata-rata pre-test kelas kontrol.

Setelah pre-test dilaksanakan di kelas eksperimen dan kontrol, selanjutnya melakukan treatment. Adapun gambaran dari proses pembelajaran dengan menggunakan media flip book di kelas eksperimen, secara umum meliputi kegiatan pendahuluan, inti dan penutup. Pada saat flip book digunakan sebagai media pembelajaran, terlihat pada kegiatan inti. Dimana flip book menjadi alat bantu untuk siswa mengumpulkan informasi ketika berdiskusi dengan kelompok, serta untuk mempresentasikan hasil diskusi yang dilakukan dengan kelompoknya masing-masing. Sementara di kelas kontrol, menggunakan media pembelajaran lain dalam proses pembelajaran. 
Proses pembelajaran dilaksanakan selama lima pertemuan. Selanjutnya, dilakukan post-test di kelas eksperimen dan kontrol. Dari data nilai post-test, diketahui kondisi akhir dari kelas eksperimen setelah treatment dilaksanakan, ditunjukkan dengan ratarata nilai sebesar 85,16 dengan interpretasi baik. Sedangkan untuk kondisi akhir kelas kontrol, ditunjukkan dengan dengan rata-rata nilai sebesar 84,24 dengan interpretasi baik. Untuk melihat adanya peningkatan kemampuan pemahaman belajar siswa di kelas eksperimen, maka perlu adanya analisis gain ternormalisasi. Gain ternormalisasi merupakan gain yang digunakan untuk mengetahui ada atau tidaknya peningkatan hasil belajar setelah dilakukan pembelajaran.
Pengolahan data dengan gain ternormalisasi, menunjukkan kelas eksperimen mengalami peningkatan pemahaman belajar sebanyak 0,66 dengan interpretasi sedang. Untuk mengetahui apakah peningkatan yang terjadi meningkat secara signifikan atau tidak, maka data pre-test dan post-test diuji dengan uji paired sample test, dengan syarat data berdistribusi normal dan homogen.

Setelah data pre-test dan post-test diketahui normal dan homogen, maka data akan dihitung dengan uji paired sample test. Adapun perhitungannya dibantu dengan aplikasi SPSS 21 sebagai berikut :

Tabel 4

Output Uji Paired Sample Test Kelas Eksperimen

Paired Samples Test

\begin{tabular}{|c|c|c|c|c|c|c|c|c|}
\hline & \multicolumn{5}{|c|}{ Paired Differences } & \multirow{3}{*}{$\mathrm{t}$} & \multirow{3}{*}{ df } & \multirow{3}{*}{$\begin{array}{l}\text { Sig. (2. } \\
\text { tailed) }\end{array}$} \\
\hline & \multirow[t]{2}{*}{ Mean } & \multirow[t]{2}{*}{$\begin{array}{c}\text { Std. } \\
\text { Deviation }\end{array}$} & \multirow[t]{2}{*}{$\begin{array}{l}\text { Std. } \\
\text { Error } \\
\text { Mean }\end{array}$} & \multicolumn{2}{|c|}{$\begin{array}{c}95 \% \text { Confidence } \\
\text { Interval of the } \\
\text { Difference }\end{array}$} & & & \\
\hline & & & & Lower & Upper & & & \\
\hline $\begin{array}{ll} & \text { Pretest } \\
\text { Pair } & \text { eksperimen - } \\
1 & \text { Posttest } \\
& \text { eksperimen }\end{array}$ & $\begin{array}{c}- \\
29.028\end{array}$ & 9.110 & 1.518 & -32.110 & -25.945 & $\begin{array}{c}- \\
19.117\end{array}$ & 35 & .000 \\
\hline
\end{tabular}

Berdasarkan output di atas, diperoleh bahwa nilai sig. (2-tailed) sebesar $0,000<0,05$, maka sesuai dasar pengambilan keputusan dalam uji paired sample t-test, dapat disimpulkan terdapat perbedaan signifikan antara nilai rata-rata pre-test kelas eksperimen dan nilai rata- rata post-test kelas eksperimen. Hal ini menunjukkan bahwa siswa kelas eksperimen memiliki peningkatan kemampuan belajar yang signifikan setelah melaksanakan proses pembelajaran dengan menggunakan media flip book. 
Sedangkan pengolahan data dengan gain ternormalisasi, menunjukkan kelas kontrol mengalami peningkatan pemahaman belajar sebanyak 0,63 dengan interpretasi sedang. Untuk mengetahui apakah peningkatan yang terjadi meningkat secara signifikan atau tidak, maka data pre-test dan post-test diuji dengan uji paired sample test, dengan

Tabel 5

Output Uji Paired Sample Test Kelas Kontrol syarat data berdistribusi normal dan homogen.

Setelah data pre-test dan post-test diketahui normal dan homogen, maka data akan dihitung dengan uji paired sample test. Adapun perhitungannya dibantu dengan aplikasi SPSS 21 sebagai berikut :

Paired Samples Test

\begin{tabular}{|c|c|c|c|c|c|c|c|c|}
\hline & & $\mathrm{Pai}$ & ed Diff & ences & & & & \\
\hline & Mean & $\begin{array}{c}\text { Std. } \\
\text { Deviation }\end{array}$ & $\begin{array}{l}\text { Std. } \\
\text { Error }\end{array}$ & $\begin{array}{r}95 \% \mathrm{C} \\
\text { Interv } \\
\text { Diff }\end{array}$ & $\begin{array}{l}\text { fidence } \\
\text { of the } \\
\text { ence }\end{array}$ & $\mathrm{t}$ & df & $\begin{array}{l}\text { Sig. (2- } \\
\text { tailed) }\end{array}$ \\
\hline & & & & Lower & Upper & & & \\
\hline \begin{tabular}{|cl}
\multicolumn{2}{|c}{ Pretest } \\
Pair & kontrol - \\
1 & Posttest \\
& kontrol
\end{tabular} & $\begin{array}{c}- \\
26.394\end{array}$ & 8.208 & 1.429 & -29.304 & -23.484 & $\begin{array}{c}- \\
18.472\end{array}$ & 32 & .000 \\
\hline
\end{tabular}

Berdasarkan output di atas, diperoleh bahwa nilai sig. (2-tailed) sebesar $0,000<0,05$, maka dapat disimpulkan terdapat perbedaan signifikan antara nilai rata-rata pre-test kelas kontrol dan nilai rata-rata post-test kelas kontrol. Hal ini menunjukkan bahwa siswa kelas kontrol memiliki peningkatan kemampuan belajar yang signifikan setelah melaksanakan proses pembelajaran.

Selanjutnya merupakan tahapan pengujian hipotesis. Untuk melihat adanya perbedaan yang signifikan antara kelas eksperimen dan kontrol, maka data yang didapat dari kedua kelas tersebut harus diolah menggunakan uji independent sample t-test. Adapun data yang akan digunakan untuk pengujian hipotesis dengan uji independent sample t-test yaitu menggunakan data nilai dari post-test kelas eksperimen dan data nilai post-test kelas kontrol.

Setelah data post-test kelas eksperimen dan kontrol diketahui berdistribusi normal dan homogen, maka data diolah dengan uji independent sample test. Adapun perhitungannya dibantu dengan aplikasi SPSS 21 sebagai berikut : 
Tabel 6

Output Uji Independent Sample test

Independent Samples Test

\begin{tabular}{|c|c|c|c|c|c|c|c|c|c|}
\hline & \multicolumn{2}{|c|}{$\begin{array}{l}\text { Levene's } \\
\text { Test for } \\
\text { Equality of } \\
\text { Variances }\end{array}$} & \multicolumn{7}{|c|}{ t-test for Equality of Means } \\
\hline & \multirow[b]{2}{*}{$\mathrm{F}$} & \multirow[b]{2}{*}{ Sig. } & \multirow[b]{2}{*}{$\mathrm{t}$} & \multirow[b]{2}{*}{ df } & \multirow{2}{*}{\begin{tabular}{|c} 
Sig. \\
$(2-$ \\
tailed $)$
\end{tabular}} & \multirow{2}{*}{$\begin{array}{c}\text { Mean } \\
\text { Difference }\end{array}$} & \multirow{2}{*}{$\begin{array}{l}\text { Std. Error } \\
\text { Difference }\end{array}$} & \multicolumn{2}{|c|}{$\begin{array}{c}95 \% \\
\text { Confidence } \\
\text { Interval of the } \\
\text { Difference }\end{array}$} \\
\hline & & & & & & & & Lower & Upper \\
\hline $\begin{array}{l}\text { Nilai Equal } \\
\text { variances }\end{array}$ & 2.253 & .138 & 617 & 67 & .540 & .924 & 1.499 & -2.067 & 3.916 \\
\hline $\begin{array}{l}\text { Equal } \\
\text { variances } \\
\text { not } \\
\text { assumed }\end{array}$ & & & 611 & 61.831 & .543 & .924 & 1.512 & -2.099 & 3.947 \\
\hline
\end{tabular}

Dari output di atas, diperoleh bahwa data homogen sehingga nilai yang dilihat adalah nilai equal variances asuumed, diketahui nilai sig. (2-tailed) sebesar 0,617 > 0,05, maka $\mathrm{H}_{\mathrm{o}}$ diterima dan $\mathrm{H}_{\mathrm{a}}$ ditolak atau dengan kata lain rata-rata hasil belajar posttest siswa yang melakukan pembelajaran dengan menggunakan media pembelajaran flip book dengan siswa yang tidak menggunakan media pembelajaran flip book dalam meningkatkan hasil belajar siswa pada pembelajaran PAI dan Budi Pekerti adalah sama.

Peneliti memperkirakan faktor-faktor yang membuat tidak terdapat perbedaan yang signifikan antara siswa yang melakukan pembelajaran dengan menggunakan media pembelajaran flip book dengan siswa yang tidak menggunakan flip book antara lain adalah karena pemahaman antara kelas eksperimen dan kontrol relatif sama. Sehingga untuk kelas kontrol yang tidak menggunakan media flip book dalam proses pembelajaran, mengalami peningkatan yang signifikan yang relatif sama dengan kelas eksperimen.

Selain itu, sebagaimana yang disebutkan tentang kerucut pengalam belajar. Edgar Dale mengelompokkan media pembelajaran berdasarkan jenjang pengalaman yang diperoleh pembelajaran. Jenjang tersebut disusun bagan yang dikenal dengan nama Kerucut Pengalaman Dale (Asyhar, 2012, hlm. 49).

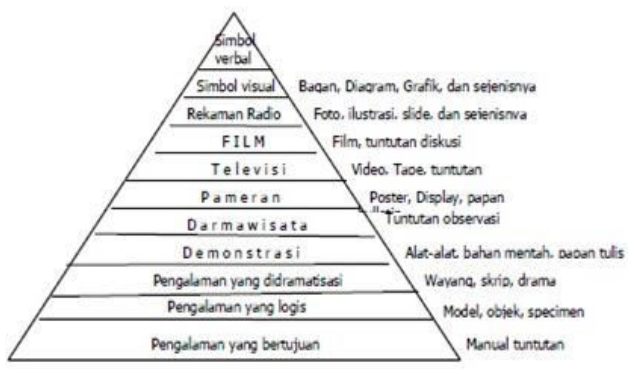

Gambar 2

Kerucut Pengalaman Edgar Dale 
Karena media flip book berbasis visual, diperkirakan siswa hanya mampu menyerap informasi sebanyak 10\%. Berbeda halnya dengan media yang berbasis audio visual yang mampu membuat siswa menyerap informasi sebanyak $60 \%$. Namun faktor-faktor yang telah dijelaskan peneliti tersebut hanya kemunginan yang terjadi, untuk lebih akurat tentang penelitian lebih lanjut, maka peneliti merekomendasikan untuk penelitian yang melibatkan multimedia.

Namun, pada hakikatnya media pembelajaran flip book efektif untuk meningkatkan hasil belajar siswa, baik itu hasil belajar siswa kelas ekperimen maupun kelas kontrol. Hal tersebut dapat terlihat dengan adanya peningkatan yang signifikan pada masing-masing kelas dalam perhitungan gain ternormalisasi. Tetapi jika hasil belajar dari kelas eksperimen yang menggunakan media flip book dalam proses pembelajaran, dibandingkan dengan hasil belajar dari kelas kontrol yang tidak menggunakan media flip book dalam proses pembelajaran, memang tidak terdapat perbedaan yang signifikan antara kedua kelas tersebut.

Hal tersebut sangat memungkinkan terjadi karena berbagai faktor. Sebagaimana yang telah dikemukakan sebelumnya, faktor tersebut bisa karena media yang digunakan, atau karena kondisi siswa dari masingmasing kelompok. Namun hal yang perlu ditekankan adalah media flip book efektif untuk meningkatkan hasil belajar siswa dalam mata pelajaran PAI dan Budi Pekerti, namun ketika dibandingkan antara kelas eksperimen dan kelas kontrol, memang tidak ada perbedaan yang signifikan dalam pengingkatan hasil belajar dalam mata pelajaran PAI dan Budi Pekerti.

\section{PENUTUP}

Berdasarkan uji hipotesis, dapat disimpulkan bahwa tidak terdapat perbedaan yang signifikan antara kelas eksperimen yang menggunakan media pembelajaran flip book dalam proses pembelajaran, dengan kelas kontrol yang tidak menggunakan media flip book dalam proses pembelajaran PAI dan Budi Pekerti. Dengan kata lain, media pembelajaran flip book yang digunakan kelas eksperimen, tidak lebih efektif dari kelas kontrol dalam peningkatan hasil belajar siswa pada mata pelajaran PAI dan Budi Pekerti di kelas XI MIA SMA Negeri 4 Bandung.

Bagi pendidik, media flip book ini memungkinkan menjadi salah satu alternatif media pembelajaran yang dapat digunakan pendidik dalam proses pembelajaran. Bahkan tidak menutup kemungkinan di tempat dan yang lain dengan kreatifitas yang tinggi, media ini bisa membantu tercapainya tujuan pembelajaran.

Adapun rekomendasi bagi peneliti selanjutnya, peneliti merekomendasikan adanya pengembangan media flip book berbasis multimedia. Karena sebagaimana yang peneliti ketahui bahwa sudah ada media flip book berbasis aplikasi flip book maker. Aplikasi ini bisa dibilang kekinian, karena menggunakan teknologi yang bisa di install dalam gadget ataupun dalam laptop. Sehingga diharapkan mampu meningkatkan hasil belajar siswa dalam proses pembelajaran PAI. 


\section{REFERENSI}

Anwar, S. (Performer). (2014). Media

Pembelajaran dan Proses

Pembelajaran. Bandung, Jawa Barat, Universitas Pendidikan Indonesia.

Asyhar, R. (2012). Kreatif Mengembangkan

Media Pembelajaran. Jakarta: Referensi Jakarta.

Hake, R. R. (1998). Interactive-engagement versus traditional methods : A six thousand student survey of mechanics test for introductory physics courses.

American Journal of Physics, Vol. 66, hlm. 65 .

Mustafidah, T. T. (2012). Penelitian

Kuantitatif. Bandung: CV Alfa Beta.

Sudjana, N. (2009). Penilaian Hasil Proses Belajar Mengajar. Bandung: PT Remaja Rosdakarya.

Sugiyono. (2010). Metode Penelitian Pendidikan Pendekatan Kuantitatif, Kualitatif, dan R\&D. Bandung: Alfabeta.

Wahidmurni, Mustikawan, A., \& Ridho, A. (2010). Evaluasi Pembelajaran: Kompetensi dan Praktik. Yogyakarta:

Nuha Letera. 